\title{
Building the Quality of Halal Investment Triangle on Murabahah Purchasing Agreement, Affected
}

\author{
Suhari
}

\begin{abstract}
The general objective of this research is to increase the service of BNI Syari'ah toward its customers in order to increase halal repurchasing. The specific objective is to analize and to test the relationship among latent variables in on empirical model; attributed satisfaction of amar ma'ruf nahi munkar (KBAN), quality of halal investment triangle (KSIH), profit sharing agreement (KBH), and halal repurchasing (PUH). The research method is descriptive statistics using SEM analysis technique with Amos-18 software. Samples are taken from the customer population of branches of BNI Syari'ah in Semarang, Pekalongan, Purwokerto and Surakarta as many as 174 respondents. The result of variable analysis testing is proven that the quality variable of halal investment triangle answers the research problem, which is "How to increase sharia customer loyalty by building quality of halal investment triangle affected on halal repurchasing".This research gives theoretical contribution of (1) developing specific management science on quality variable of halal investment triangle affected on halal repurchasing; (2) contributing on the future reasearch through basic theoretical model in this research which is not thoroughly tested empirically; and (3) contributing on management practice in order to further increase customer's loyalty, so that organization or corporate can be more effective and efficient in order to enhance the decision of halal repurchasing.
\end{abstract}

Index Terms-Attributed satisfaction of amar ma'ruf nahi munkar (KBAN), quality of halal investment triangle (KSIH), profit sharing agreement (KBH), halal repurchasing (PUH).

\section{INTRODUCTION}

It is an important strategy to gain long-term benefit, to build, and to develop customers' loyalty. A faithful and loyal customer will always repurchase from the same company, tell other potential customers by the power of words of mouth [1]. It is showed that each 5\% increase on customers' loyalty can increase benefits to $25 \%-85 \%$. Thus it can be uttered that a company's success is determined by its customer's loyalty [2].

According to [3], the types of sharia financing according to its purpose is differed into the financing of sharia working capital, sharia investment, and sharia consumptive with profit sharing principal. We also often hear a proverb saying that customers ar kings that have to be served as good as possible. The excellence of service quality is hoped to be able to interest consumer's steadiness to re-gain tendency to repurchase on our offered products, this is in accordance with the reasearch of [4].

Manuscript received August 12, 2014; revised April 30, 2015.

Suhari is with the Diponegoro University, Semarang, Indonesia (email: roszeko@yahoo.co.id).

\section{RESEARCH OBJECTIVES}

This research generally aims to 1) contribute to the government (Bank of Indonesia) to further improve the regulation of Islamic banks in order that the image is trusted by society; 2) support the improvement of sharia bank service to the customers and always hole product innovation to increase sharia customer satisfaction and aim to customer loyalty.

Based on general objectives, specific objectives which will be achieved in this research can be specified as follows: 1) To test and analyze the effect of attributed satisfaction on amar ma'ruf nahi munkar toward halal repurchasing; 2) To test and analyze the effect of attributed satisfaction on amar ma'ruf nahi munkar toward the quality of halal investment triangle; 3) To test and analyze the effect of the quality of halal investment triangle toward halal repurchasing; 4) To test and analyze the effect of attributed satisfaction on amar ma'ruf nahi munkar toward profit sharing agreement; 5) To test and analyze the effect of profit sharing agreement toward halal repurchasing.

\section{RESEARCH BENEFIT}

Theoretically this research has the following benefits : 1) To contribute in the management science, particularly in the theory of halal repurchasing; 2) To contribute in the knowledge management, particularly in the use of quantitative models and empirical testing; 3 ) To contribute in the theory, the quality variable quality of halal investment triangle which has significant effect on the increase of halal repurchasing; 4) To contribute in the following research agenda through basic theoretical model in which it has not been able to be thoroughly tested empirically in this research.

Practically this research has benefits to: 1) provide thought contribution in management practice in order to increase quality of halal investment triangle, so that organization (company can be more effective and efficient in determining marketing in order to motivate halal repurchasing); 2) provide benefits for management thought that marketing theory is not only demanding on the profits but also social responsibility on the consumers.

\section{RESEARCH ORIGINALITY}

The objects of this research is in BNI Syari'ah in Semarang, Pekalongan, Purwokerto and Surakarta in Central Java Province, Indonesia. In this research, the researcher developed investment theory in the conventional 
economy concept, that investment is viewed as an activity which gives financial satisfaction and benefit rate in the future [5].

Recently, the tendency of investment motivation starts to experience a shift, not only in finacial satisfaction but also in spiritual satisfaction [6]. The tendency for such investment is called Islamic ethical investment, halal investment. In this research, a new variable of the quality of halal investment triangle is developed.

The quality variable of halal investment triangle is an original variable used in this research. It is as mediation variable which is percepted to be able to bridge input and output, so that it can improve loyalty which has positive effect on halal repurchasing.

The quality variable of halal investment triangle is expected to be able to contribute in the previous researches about satisfaction which has not been able to increase halal repurchasing. Moreover, as an effort to mediate satisfaction relationship gap toward halal repurchasing, a new variable, quality variable of halal investment triangle, is used.

\section{LITERATURE REVIEW AND HYPOTHESIS}

\section{A. Attributed Satisfaction on Amar Ma'ruf Nahi Munkar (KBAN)}

Customer satisfaction is a necessary foundation for the company to retain existing customers, as put forward by [1], [7]. Customer satisfaction is an explanation and a perception that customers wants to make sure their purchase due to the intention to get back the incurred cost after making a purchase, it in accordance with the finding of [8]. The manifestation (a manifestation of expressing feeling or opinion) on satisfaction varies from one person to another and from one product to another [1], [9].

Concluded that the concept of satisfaction is a common perception of services reduced by the same service and perceived service quality and effect on customer satisfaction.

Customer satisfaction is the degree to which the needs, wants and expectations of customers are met which will result in repeat purchases or continued loyalty [10].

Ref. [11] had done a survey to measure customer satisfaction and preferences in Islamic banking in Jordan, to assess the level of customer awareness and satisfaction on Islamic banks in Jordan toward Islamic product attributes which becomes the main reason why customers choose to use shariah bank and becomes an assessment indicator for the customers. Satisfaction will be perceived by the customer when the existing Sharia value the attributes of Sharia bank product is higher.

Ref. [12] stated that the development of sharia banks in the future cannot be separated from information gathered through scientific studies. Recommendations of the results of scientific research will give a big contribution for banking units in order to build its marketing strategy in order that markets can be achieved and customer satisfaction can be created, as well as to give correct and trustworthy information to the society, so that they have great will to take advantage of sharia banking service.

Ref. [13] had done a research about customer satisfaction by seeing retention (maintenance) of bank customers in
New Zealand. They examined the impact of some relevant retention that influences consumer's decision to remain a customer or leave their bank in New Zealand. The system that has been assessed by the customers has a powerful effect on loyalty to their bank. Their research result reveals that the most important system is customer satisfaction, followed by company image and switching barriers (transition). There is also a prove in the research that the age of customer group and the level of education contribute to explain respondents' decision to remain a customer in their current bank.

Amar ma'ruf is a command to do a good deed. Nahi munkar is a prohibition to prevent disobedience and to stay away from sins [14]. Amar ma'ruf nahi munkar in Islamic law is command and prohibition. Intentions and attitudes of Amar ma'ruf nahi munkar is one unity/correlation that is inseparable from one another. Nahi munkar will not have optimal plus point if it is not conducted together with amar ma'ruf. Satisfaction formulating intentions and attitudes of adjoined Amar ma'ruf nahi munkar will increase more and may be much more satisfied feeling of sharia customers, because in either long or short term, it can meet the expectation according to the needs and desires of sharia customers.

In accordance with the western philosophy science, amar ma'ruf nahi munkar (commanding the good and forbidding the evil) is called social engineering (social effort) law, while nahi munkar (forbidding the evil) is called social control, [1], [15]. Social control is a normative aspect of social life or is referred to as a control against deviant society behavior. While the social effort is as a tool to change people's behavior done by one or more leaders of social institutions [1], [16].

Based on the above theory, it has a meaning that attributed satisfaction of amar ma'ruf nahi munkar is an interaction between sharia products, banking service according to sharia aspect, Islamic law that can formulate the feeling of satisfaction so that it can effect on customers' emotional bond toward sharia aspect marketing and avoid non sharia can also effect on the quality of halal investment triangle [2], [15].

\section{B. Quality of Halal Investment Triangle (KSIH)}

According to [1], [17], the meaning of product quality is the ability of a product to perform its functions, it includes the product's overall durability, reliability, precision, ease of operation and repair, and other valued attributes.

Ref. [1], [18] Stated that service quality is something that is percepted by customers. They will value the quality of a service felt by what they describe in their mind. Customers will shift to other service providers which have more capabilities in understanding their specific needs and give better service.

There are 5 dimensions of service quality according to [19], among others are: Physical evidence (tangibles), focuses on elements representing service physically, including physical facilities, location, used tools and equipments (technology), and the performance of its employees. Reliability is an ability to give service precisely according to what is promised before which includes performance suitability in the hope that customers that mean 
time accuracy, the same service to all customers, sympathetic attitude and high accuracy. Responsiveness is an ability to help and give correct and responsive service to the customers with clear information. This dimension emphasizes on personnel behavior in providing service to pay attention on the request, questions, and objections of the customers. Assurance is an ability to deliver trust and belief inside the customers, which include knowledge, courtesy, and ability of company employees to develop customers' trust toward the company. Empathy emphasizes on the treatment to the customers as individuals which include requirements to care, to have understanding and knowledge about customers, to understand customers' needs specifically, as well as to have comfortable operation time for the customers.

Triangle in this research is an integrated cooperation form and fully conduct sharia aspect between service/good provider, sharia bank, and sharia customers. This cooperation is called triangle collaboration by the researcher [20].

The word of investment is an adopted word from English language. The word to invest is a basic word of investment which means to plant. Simply, investment can have the meaning of a wealth planting activity which has a purpose to develop it. More practically, investment is a commitment on a number of fund and other resources which is done in the present time in the hope that it will gain a number of benefits in the future [21].

The measurement of investment success is not only determined by higher return rate as concepted in conventional economy. Recently, the tendency for investment motivation tends to shift, where it is not only viewed as an activity that gives financial satisfaction or higher return rate, but also spiritual satisfaction [22].

Conventional investment behavior is believed by many people to contribute in various world economy crisis. For example, great depression in the 1930's was started with enormous speculation in Wall Street, Besides, Poundsterling devaluation in 1967 and Frank currency crisisi in 1969. And finally the devaluation of Thailand's Baht caused tremendous investment withdrawal in the capital market which then caused economy crisis. Those elements, according to Esta, brought a realization to the investors on the importance of more ethical investment [23].

Halal is an Arabic word meaning allowed or permitted. It is not only valid on food, but also relationship among people, clothing, business, job, finance, investment, etc, [24]. Halal is not only about religion, but this has been int the business word and trading and become a global symbol for quality guarantee and lifestyle. Halal products are according to the sharia (Islamic law) which does not include the use of haram (forbidden) things, exploit labor force and dangerous environment or aimed for the dangerous use.

The scope of halal can also include all consumables things like toiletries, medicines, cosmetics, including financial service. Halal is a proses attributs on specific trust, which is a quality characteristic that cannot be evaluated or determined by individual consumer [25].

Ref. [1], [26] defined halal as everything that could be done, allowed by the sharia and people who do it will not get sanction from the God.
Quality of halal investment triangle is a form of trading agreement of murabahah financing system among the three elements, sharia banks, service/good provider, customers, by conducting entire sharia system. Therefore those three elements always collaborate in doing sharia business regulation thoroughly, which are honest, fair, and transparent, so that it will effect mutually for all elements. If one of the elements break the agreement, it will badly effect all the elements as well. Thus quality of halal investment triangle in murabahah trading contract can be perceived as having positive effect on halal repurchasing [1], [20].

\section{Profit Sharing Agreements}

The increasing profit-sharing-based financing according to [1], [27], has some benefits, such as 1) mudharabah and musyarakah financing will move real sectors, because this financing is productive, distributed for investment and working capital needs. If investment in real sectors increases it will create new job opportunity so that it can decrease unemployment as well as increase people's income; 2) customers will have two choices, whether they will deposit their fund at sharia bank or conventional one. They will compare between expected rate of return offered by sharia banks with the interest rate of conventional banks. Where all this time, the tendency of sharia banks' rate of return is higher than conventional banks' interest rate. Thus it is expected that it will become the booster of the increase number of the customers in sharia banks; 3 ) the percentage increase of profit sharing financing will boost the growth of entrepreneurs or investors who dare to take risky business decision. In the end, new innovation will develop which will increase sharia banks' competitiveness; 4) the pattern of mudharabah and musyarakah financing is the pattern of productive-based financing which give plus point to economy and real sector so that the possibility of financial crisis can be decreased. Besides, by optimizing profit sharing financing in sharia banks it can develop customers' entrepreneurship spirit which then can increase income distribution and enforce people's economy.

In doing its activities, sharia bank has the following principals: 1) principle of justice, this principal is reflected from the implementation of compensation on the basis of profit sharing and the profit margin taking which is agreed between the bank and its customers; 2) principal of equality. Sharia banks put fund deposit customers, fund user customers, as well as the bank in an equal position. This is reflected on the equal profit, risk, responsibility, and right between fund deposit customers, fund user customers, as well as the bank; 3) principal of peace. Sharia bank products are in accordance with Islamic Muamalah rules and principals, which are the nonexistence of riba and the implementation of zakat (Islamic charity) of wealth. Thus customers will feel in peace physically and mentally. The sharia principals will take sharia bank customer's preferrence. According to [28], financing using sharia system is more suitably implemented in financing Middle Small Micro Business (UMKM) sector because it will give more on its certainty dan will not burdened by the increase of interest rate.

Principles of trading include 1) murabahah : good buying and purchasing agreement as much as the real price of the 
goods added with profit margin agreed between sharia bank as the seller and customers as the buyers which payment is done in installment. The following is financing mechanism according to salam contract; 2) salam: an agreement of good trading in full upfront payment by sharia bank as the buyer abd customers as the sellers who are obliged to deliver the ordered goods according to the agreed time period, criteria, and requirements, and the particular good will be resold by sharia bank to other parties; 3) istishna: and agreemet of good trading which order is according to the agreed time period, criteria, and requirements, which payment is in installment by the customers as the buyer to sharia bank as the seller after the ordered good is received by the customers. Ref. [29] states that the contract that are widely used in financing the principle of trading are murabaha, salam and istishna'. While on the principle of profit sharing, the widely used contracts are mudharabah and Musyarakah.

Ref. [30] Stated that the pattern of profit sharing allows customers to directly supervise the performance of Islamic banks by monitoring the number of the obtained profit sharing. The greater the number of bank profits, the greater the results received by the customer, and vice versa. A small amount of profit sharing or decreases for long enough time is an indicator that the management of the bank declines. This is an easy and transparent early warning for the customers. Different from conventional banking, customers can not assess the performance only from the earning interest.

According to [31], the types of Sharia financing based on its purpose is divided into financing of sharia working capital, financing of Sharia investment and financing of sharia consumptive which principle is profit sharing. Principle of a lease or rental (Ijarah) is an agreement of a lease and rental of a particular good (ijarah assets or ijarah money) between sharia bank that is renting and customers as the party who lease in a certain time period. Ijarah asset is an asset gained or purchased by sharia banks in order to be rented. Whereas ijarah money is the downpayment of the lease paid by the bank to the owner of the good, which then is rented to the customers. This is the mechanism of financing based on ijarah agreement. Qardh or service principal-based financing is an agreement of lending and borrowing fund sharia bank as the lender and customer as the borrower which must return what he borrows. The loan capital without interest, which is agreed in advance is paid all at once or in installment in a certain period of time.

Sharia banking must be always consistent and real evidence must be emphasized, that Islamic banking or sharia banking is not just from an ordinary bank, but also a banking that provides benefits to its customers, by various kinds of financing products like mudharabah, musyarakah, murabahah an offered scheme finance. The support of various sharia banking products, facilities, and adequate technology will attract customers' attention and prove that sharia banking is not just an ordinary bank [32].

The existence of sharia bank must be able to contribute the increase of real sector growth, this function will be realized if sharia banks use profit and loss sharing (mudharabah and musyarakah) agreement as its core product in accordance with the finding of [33].
The increasing profit-sharing-based financing according to [2], [27], has some benefits, such as 1) mudharabah and musyarakah financing will move real sectors, because this financing is productive, distributed for investment and working capital needs. If investment in real sectors increases it will create new job opportunity so that it can decrease unemployment as well as increase people's income; 2) customers will have two choices, whether they will deposit their fund at sharia bank or conventional one. They will compare between expected rate of return offered by sharia banks with the interest rate of conventional banks. Where all this time, the tendency of sharia banks' rate of return is higher than conventional banks' interest rate. Thus it is expected that it will become the booster of the increase number of the customers in sharia banks; 3 ) the percentage increase of profit sharing financing will boost the growth of entrepreneurs or investors who dare to take risky business decision. In the end, new innovation will develop which will increase sharia banks' competitiveness; 4) the pattern of mudharabah and musyarakah financing is the pattern of productive-based financing which give plus point to economy and real sector so that the possibility of financial crisis can be decreased. Besides, by optimizing profit sharing financing in sharia banks it can develop customers' entrepreneurship spirit which then can increase income distribution and enforce people's economy.

Profit sharing principal is very good from sharia point of view, because this system is fairer than interest system. Even interest system can be categorized as riba which is definitely haram. Generally, profit sharing system is a cooperation between two parties in doing business [2], [16]. The first party is the businessman who provides fund in expertise, skill, facility and time to manage the business. While the second party is the investors who own the fund to finance the business in order to be able to operate, either working capital, or entire capital. The guarantee that the capital will return is also not the characteristics of profit sharing business, because actually investors also have risks if their business keeps losing until they do not own their capital anymore. Profit sharing in economics dictionary is defined as profit/return. In the mechanism of sharia finance unit, profit sharing income is applied on the products of capital participaion and association, either thorough or partly participation or the form of corporate business (cooperation). The shared profit must be shared propotionally between shibbul maal and mudharib according to the previously agreed agreement.

Profit sharing is also associated with philosophy. The link generates the protection of the rights of individual property ownership, but also as precautions against gluttony and greed as well as the creation of justice, as well as a way for each individual to excel and compete fairly [2], [26].

Profit sharing agreement is also a two-party cooperation which will result in profit or plus point where the shared amount of the fund owner and the bank are not determined in advance, but the the amount of the ratio [34]. The accepted amount of the fund owner or the bank depends on the result obtained from profit sharing distribution mechanism used. There are at least two distribution mechanism used, they are profit sharing and revenue sharing. Profit sharing is if profit distribution is determined 
by the profit obtained by the bank, while revenue sharing is if profit distribution is based on the obtained income. Here it can be concluded that profit sharing income is a bigger and halal income than the interest. Profit sharing system is considered as to be able to mediate the above dilemma. Stated that profit sharing is to share some of the company's profit to their employees as additional income outside of wages which are periodically accepted. Some industrialized countries have successfully implemented this system in order to maintain the stability of employment absorption as well as to increase the labor's income.

Ref. [35] found that there is no fixed and certain return like interest in the nisbah attribute of profit sharing, but profit and loss sharing are done based on real productivity of the particular products.

The concept of profit sharing in sharia financing uses mechanism of profit sharing and loss sharing because it contains distributive justice dimension and equal business partnership relationship. The suggestion is, the decrease of profit sharing system financing is better viewed propotionally by all stakeholders, including regulators who issued policy, by paying attention to all related aspects. The increase of Islamic human resource quantity and quality can be gradually, and continuously done periodically for short and long term [1], [36].

Eventhough some events have shown the implementation of mudharabah and musyarakah, the explanation is not specified yet. As a result, the specified explanation is done by fukaha (Islamic law/fiqh expert). Those fukaha emphasizes the need of these methods (mudharabah and musyarakah) for the welfare of mankind. Because the following events often occur: 1) a person possesses capital but can not run his business; 2) on the other way, a person has a strong will to have a business, he does not have the capital; 3) two or more people possess the capital but they want to cooperate in order to build a strong and more efficient business; 4) one or some parties possess the capital but they can not build the business by themselves, the can not even properly think about the right partner. Thus, other groups with skills and experience may join the business agreement based on musyarakah and mudharabah [37].

The amount of profit sharing can be calculated from company's income statement. The profit or the loss of a business is the result of the reduction between total income minus total expense, but total income can be predicted based on the previous income data from the business done by using scatter diagram and regression method. The future income prediction is aimed as a controller so business performance can be done optimally. Syari'ah Mandiri Bank (2001) which one of its operational principles is based on principle of justice, stated that the profit sharing between the bank and the businessman is based on the volume of reall selling, based on the amount of each capital contribution and the agreed risk position. Unfortunately, sharia bank determined the sharing based on nisbah determined by an agreement between the businessman and the bank. Therefore, [38] Combined the calculation of profit sharing nisbah based on each capital contribution which risk rate is according to combined opinion of some experts calculated by analytical hirarchy process (AHP) (see Fig. 1).

\section{Purchase Re-Halal (PUH)}

The basic theory of loyalty is developed in empirical model into repurchasing, and then is developed with sharia attribute into halal repurchasing.

Customers' loyalty is not only limited on loyalty and disloyalty, but also on the category of fake and latent loyalty [1], [39], [40] Found that a less loyal customer is caused by a sensitivity on the lower price. The category level of customer loyalty relationship can be seen at the following Table I.

TABLE I: CUSTOMER LOYALTY RELATIONSHIP

\begin{tabular}{|c|c|c|c|}
\hline \multirow{4}{*}{ Relative Attitude } & \multicolumn{3}{|c|}{ Repeat Patronage } \\
\hline & & High & Low \\
\hline & High & Loyalty & Latent Loyalty \\
\hline & Low & Spurious Loyalty & No Loyalty \\
\hline
\end{tabular}

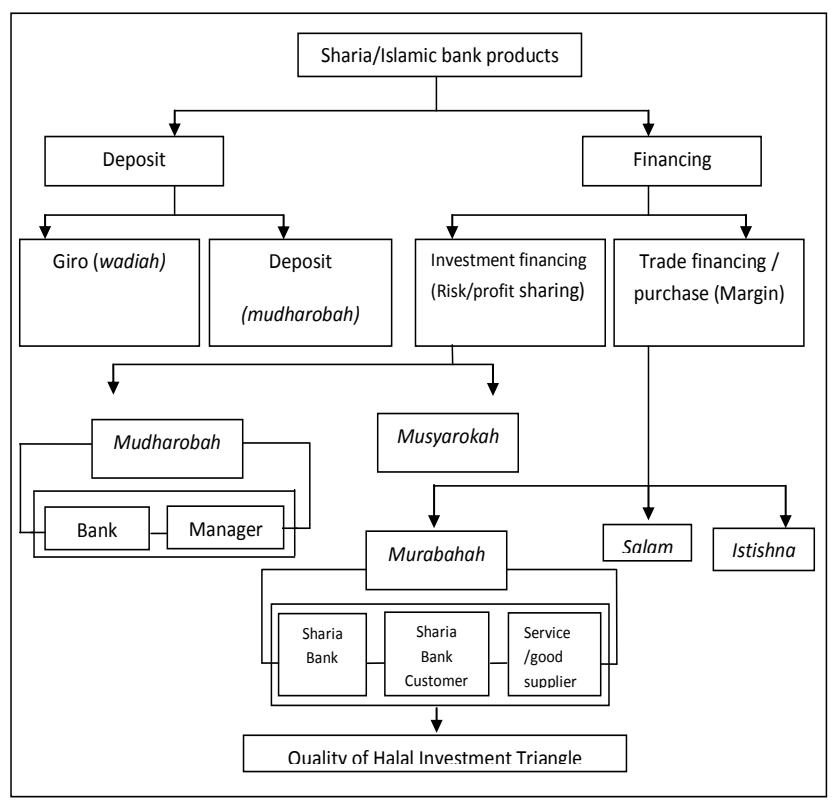

Fig. 1. Diagram on the quality of halal investment triangle. (Source: developed for this research).

Ref. [41] stated that customer loyalty is considered as having important purpose for the existence and the growth of a company, to build the basis of loyal customer does not only become the main purpose of marketing, but also becomes the important foundation to develop ongoing competitive excellence [2], [42], stated that the succeed on a brand in the long term is not based on the number of consumers who purchase once, but on the number of consumers who repurchases. To gain a new customer needs a relatively higher cost and grows into a loyal consumer.

The satisfaction theory on loyalty is very important for the advancement of company performance, but it turns out that in the research, it is found that there is no significant direct effect between customer satisfaction and loyalty. [43]-[45] stated that a loyal customer on a brand is willing to move to other brands although they have been satisfied by their regular brand.

Another research is that satisfaction has a significant direct effect on loyalty [46]. In business introduction, the level of the high employee welfare causes bigger customer satisfaction, loyalty, and productivity [47]. 
Customer loyalty and consumer behavior must be reviewed through a consideration of a situation of "disloyal" which is translated into 'disloyalty' [3], [39] Disloyalty in loyalty behavior is divided into four categories: disturbed, disappointed, releasing, and disturbing.

After purchasing a product, consumers then evaluate their purchased product or service. The evaluation will be used for the foundation to repurchase. One of the definitions about repurchasing was stated by [48], a repurchasing on the same product and service caused by marketer activities. Furthermore, the definition of repurchasing was stated by [49], where repurchasing is when a consumer often purchase the same product repeteadly. The definition gives a picture that repurchasing behavior is a behavior where consumers purchase the same product or service repeteadly.

One of the measurements that the market can be maintained and increased is the existence of repurchase or repurchasing on the same product or brand. [1], [50] stated that repurchase by the consumer is very important in maintaining profitability and business succeses. [1], [51]. Stated that loyal consumers are not measured from how much they purchase, but from how often they repuchase, including recommend other people to purchase.

Ref. [52] defined repurchase as a repurchasing activity done by the consumers on a product with the same brand without being followed by a meaningful feeling toward the particular product. There are two possibilities that can cause someone to repurchase a product. First, consumers are satisfied with their purchase. Second, customers are dissatisfied, but they keep repurchasing. This is because they think that the cost which they must spend to search, evaluate, and adopt a product with other brands (switching cost) is too high. [1], [53] Found that repurchase rates is a percentage rate of customers who purchase the same brand on the opportunity to purchase that particular product.

In accordance with the above explanation, this research suggests the following hypotheses:

H1. The higher the attributed satisfaction of amar ma'ruf nahi munkar, the higher the halal repurchasing.

H2. The higher the attributed satisfaction of amar ma'ruf nahi munkar, the higher the quality of halal investment triangle.

H3. The higher the quality of halal investment triangle, the higher the halal repurchasing.

H4. The higher the attributed satisfaction of amar ma'ruf nahi munkar, the higher the profit sharing agreement.

H5. The higher the profit sharing agreement for the building of profit sharing equity, the higher the halal repurchasing.

Based on the study of the theory of quality on halal investment triangle above, the following diagram is constructed as follows:

\section{RESEARCH FRAMEWORK}

In accordance with the above hypotheses, the framework of this study can be described in the following.

The object of this research is customers of branch offices of BNI Syariah (Semarang, Surakarta, Pekalongan and
Purwokerto in Central Java Province). The types of this research are fundamental and basic research aiming to participate on the development of science, [54]. The type of this research, according to its purpose, is descriptive research, a research giving a more detail description about a symptom or phenomenon. Meanwhile, according to data collecting technique, this research is included in quantitative research. The population of this research is customers of branch offices of BNI Syariah (Semarang, Surakarta, Pekalongan and Purwokerto in Central Java Province) as many as 2878 . The number of samples is 240 . The return sample and can be used is 199 , while after going through assumption testing, the number of sample that is used is 174 . Structural Equation Modeling (SEM) and the AMOS program version 18 are used to analyze the framework of this research (see Fig. 2).

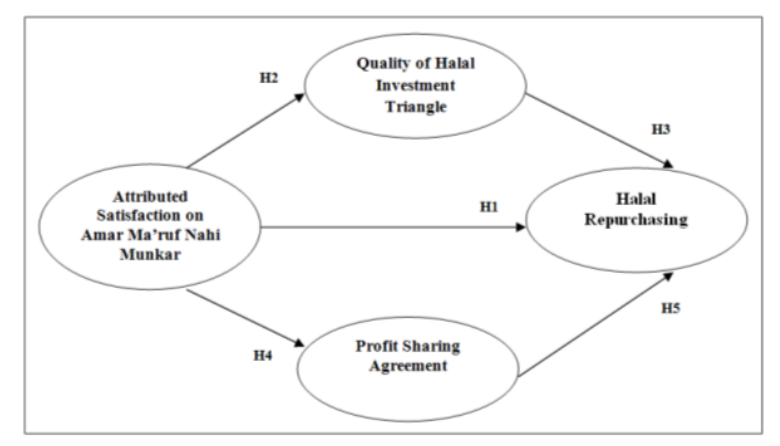

Fig. 2. Influence of attributed satisfaction on Amar Ma'ruf Nahi Munkar toward Halal repurchasing through the quality of Halal investment triangle. (Source: developed in this research).

TABLE II: REGRESSION WEIGHTS

\begin{tabular}{|lll|r|r|r|r|c|}
\hline & & & Estimate & S.E. & C.R. & P & Label \\
\hline KBH & $<--$ & KBAN &, 853 &, 092 & 9,265 & $* * *$ & H4 \\
\hline KSIH & $<---$ & KBAN &, 891 &, 095 & 9,421 & $* * *$ & H2 \\
\hline PUH & $<---$ & KBH &, 186 &, 070 & 2,656 &, 008 & H5 \\
\hline PUH & $<---$ & KSIH &, 721 &, 328 & 2,196 &, 028 & H3 \\
\hline PUH & $<---$ & KBAN &, 035 &, 320 &, 108 &, 914 & H1 \\
\hline
\end{tabular}

Source: Used in this research, 2014

TABLE III: STANDARDIZED REGRESSION WEIGHTS

\begin{tabular}{|c|c|c|c|}
\hline & & & Estimate \\
\hline $\mathrm{KBH}$ & $\begin{array}{l}<-- \\
\end{array}$ & KBAN & ,720 \\
\hline KSIH & $<--$ & KBAN & ,926 \\
\hline PUH & $<--$ & $\mathrm{KBH}$ &, 223 \\
\hline PUH & $<---$ & KSIH & 699 \\
\hline PUH & $<--$ & KBAN & 035 \\
\hline KBAN4 & $<--$ & KBAN & ,738 \\
\hline PUH1 & $<--$ & PUH &, 815 \\
\hline PUH2 & $<--$ & PUH & ,797 \\
\hline PUH3 & $<--$ & PUH & ,773 \\
\hline KBAN1 & $<--$ & KBAN & ,749 \\
\hline KBAN2 & $<--$ & KBAN & ,808 \\
\hline KBAN3 & $<--$ & KBAN & ,793 \\
\hline $\mathrm{KBH} 2$ & $<--$ & $\mathrm{KBH}$ & ,927 \\
\hline KBH1 & $<--$ & $\mathrm{KBH}$ & ,986 \\
\hline KBH3 & $<--$ & $\mathrm{KBH}$ &, 592 \\
\hline KSIH2 & $<---$ & KSIH & ,684 \\
\hline KSIH1 & $<--$ & $\mathrm{KSIH}$ & ,774 \\
\hline KSIH3 & $<--$ & KSIH &, 771 \\
\hline
\end{tabular}




\section{HyPOTHESIS DISCUSSION AND TESTING}

The result of hypothesis testing on Table II can be seen that not all variable has positive relationship, where not all hypothesis of the five hypothesis built in this research can be accepted. It turned out that four hypotheses are accepted and one hypothis is rejected.

\section{RESUlT OF HyPOTHESIS TESTING}

H1. The higher the attributed satisfaction of amar ma'ruf nahi munkar, the higher the halal repurchasing.

Estimation parameter for testing the effect of attributed satisfaction on Amar Ma'ruf Nahi Munkar on halal repurchasing shows insignificant results with $\mathrm{CR}$ value = 0,108 with probability $=0,914$ that value does not qualify hypothesis requirement of $\mathrm{C}$. $\mathrm{R}$ value $=\geq 1.96$ and $\mathrm{P}$ value $=0,914$ insignificant because the value is above 0.05 or $5 \%$ so there is no reason to accept $\mathrm{H} 1$. These results indicate that the variable of attributed satisfaction on amar ma'ruf nahi munkar has insignificant effect on halal repurchasing. The results explain that the attributed satisfaction on amar ma'ruf nahi munkar developed by the customers does not have great effect on halal repurchasing.

H2. The higher the attributed satisfaction of amar ma'ruf nahi munkar, the higher the quality of halal investment triangle.

Estimation parameter for testing the effect of attributed satisfaction on Amar Ma'ruf Nahi Munkar on the quality of halal investment triangle shows significant results with $\mathrm{CR}$ value $=9,421$ with probability $=* * *$ that value qualifies hypothesis requirement of $\mathrm{C}$. $\mathrm{R}$ value $=\geq 1.96$ and $\mathrm{P}$ value $=* * *$ significant because the value is below 0.05 or $5 \%$ so there is no reason to reject $\mathrm{H} 2$. These results indicate that the variable of attributed satisfaction on amar ma'ruf nahi munkar has significant effect on the quality of halal investment triangle. The results explains that the attributed satisfaction of Amar Ma'ruf Nahi Munkar developed by the customers has great effect on the quality of halal investment triangle.

H3. The higher the quality of halal investment triangle, the higher the halal repurchasing.

Estimation parameter for testing the effect of attributed satisfaction on Amar Ma'ruf Nahi Munkar on the quality of halal investment triangle shows significant results with CR value $=2,196$ with probability $=0,028$ that value qualifies hypothesis requirement of $\mathrm{C}$. $\mathrm{R}$ value $=\geq 1.96$ and $\mathrm{P}$ value $=0,028$ significant because the value is below 0.05 or $5 \%$ so there is no reason to reject $\mathrm{H} 3$. These results indicate that the variable of attributed satisfaction on Amar Ma'ruf Nahi Munkar has significant effect on halal repurchasing. The results explains that the attributed satisfaction on Amar Ma'ruf Nahi Munkar developed by the customers has great effect on halal repurchasing.

H4. The higher the attributed satisfaction of amar ma'ruf nahi munkar, the higher the profit sharing agreement.

Estimation parameter for testing the effect of attributed satisfaction on Amar Ma'ruf Nahi Munkar on profit sharing agreement shows significant results with $C R$ value $=9,265$ with probability $=* * *$ that value qualifies hypothesis requirement of $\mathrm{C}$. $\mathrm{R}$ value $=\geq 1.96$ and $\mathrm{P}$ value $=*$ **significant because the value is below 0.05 or $5 \%$ so there is no reason to reject $\mathrm{H} 4$. These results indicate that the variable of attributed satisfaction on amar ma'ruf nahi munkar has significant effect on profit sharing agreement. The results explains that the attributed satisfaction on amar ma'ruf nahi munkar developed by the customers has great effect on profit sharing agreement.

H5. The higher the profit sharing agreement for the building of profit sharing equity, the higher the halal repurchasing.

Estimation parameter for testing the effect of profit sharing agreement on halal repurchasing shows significant results with $\mathrm{CR}$ value $=2,656$ with probability $=0,008$ that value qualifies hypothesis requirement of $\mathrm{C}$. $\mathrm{R}$ value $=\geq$ 1.96 and $\mathrm{P}$ value $=0,008$ significant because the value is below 0.05 or $5 \%$ so there is no reason to reject H5. These results indicate that the variable of profit sharing agreement has significant effect on halal repurchasing. The results explains that profit sharing agreement developed by the customers has great effect on halal repurchasing.

\section{CONCLUSION OF HYPOTHESIS}

H1. The higher the attributed satisfaction of amar ma'ruf nahi munkar, the higher the halal repurchasing.

Hypothesis one is not proven that the higher the sharia attributed satisfaction of Amar Ma'ruf Nahi Munkar, the higher the halal repurchasing. The result of this research does not support the previous research that customers or consumers satisfaction must be maintained in order to always use our offered products. Consumers have the right to determine their choice in gaining satisfaction when served by a company which offers a particular product. [52], [2] Defined repurchase as a repurchasing activity done by the consumers on a product with the same brand without being followed by a meaningful feeling toward the particular product.

H2. The higher the attributed satisfaction of amar ma'ruf nahi munkar, the higher the quality of halal investment triangle.

Hypothesis 2 is proven that the higher the attributed satisfaction of Amar Ma'ruf Nahi Munkar, the higher the quality of halal investment triangle. The result of this research supports the previous study result that customer satisfaction is the foundation needed by the company to maintain its existed customers [2]-[7]. Customer satisfaction is an explanation and perception that customers determine their purchase, because they want that the spent cost can return after purchasing [55]. The manifestation of this feeling or opinion on satisfaction is varied from one person to another and from one product to another [2], [9]. [35] concluded that the concept of satisfaction is a common perception of services reduced by the same service and perceived service quality and effect on customer satisfaction.

H3. The higher the quality of halal investment triangle, the higher the halal repurchasing.

Hypothesis 3 is proven that the higher the quality of halal investment triangle, the higher the halal repurchasing. The result of this research supports the previous study result that according to [2], [17], the meaning of product quality is the ability of a product to perform its functions, it includes the 
product's overall durability, reliability, precision, ease of operation and repair, and other valued attributes. [2], [18], According to service quality is something that is percepted by customers. They will value the quality of a service felt by what they describe in their mind. [2], [53] Found that repurchase rates is customer percentage rate which purchases the same brand on the opportunity to purchase the particular type of product (see Fig. 3-Fig. 5).

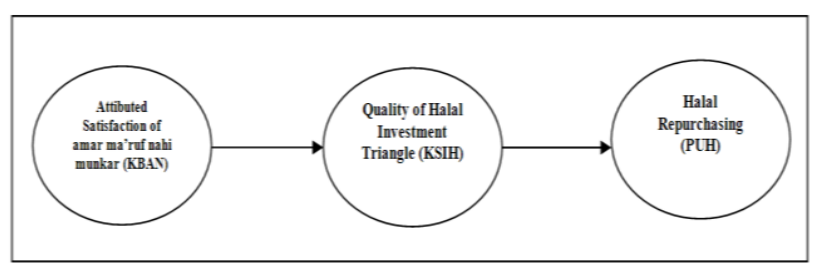

Fig. 3. The increase of halal repurchasing and mediation variable of the quality of halal investment triangle.

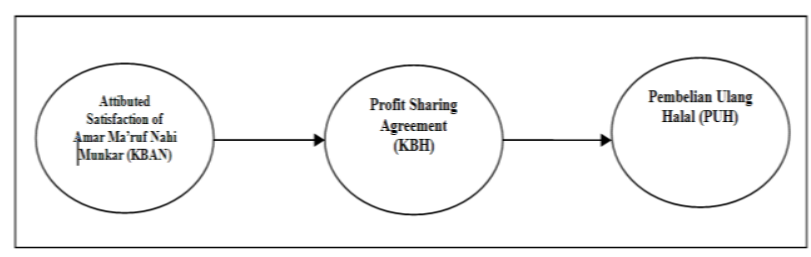

Fig. 4. The increase of halal repurchasing and mediation variable of the profit sharing agreement.

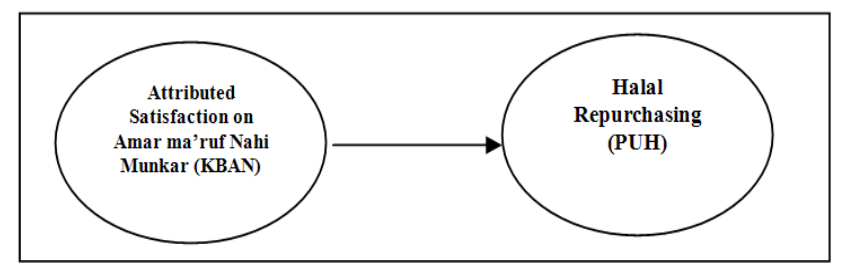

Fig. 5. Direct Relationship between attributed satisfaction on Amar Ma'ruf Nahi Munkar and halal repurchasing.

H4. The higher the attributed satisfaction of amar ma'ruf nahi munkar, the higher the profit sharing agreement.

Hypothesis 3 is proven that the higher the attributed satisfaction of Amar Ma'ruf Nahi Munkar, the higher the profit sharing agreement. The result of this research supports the previous study result that the increase of the service toward the customers is a very important matter in determining thr increase of customer satisfaction, because they have a very big role in contributing income directly or indirectly in supporting the existence of the company [56]. [57] Stated that the positive attitude of sharia bank customers and fulfill the feeling of justice in building partnership as well as more profitable must be maintained by the management of sharia banking. The concept of profit sharing in sharia financing uses mechanisms of profit sharing and loss sharing because it contains distributive justice dimension and equal business partnership relationship. The suggestion is, the decrease of profit sharing system financing is better viewed proportionally by all stakeholders, including regulators who issued policy, by paying attention to all related aspects. The increase of Islamic human resource quantity and quality can be gradually, and continuously done periodically for short and long term [2], [36].
Hypothesis 3 is proven that the higher the attributed satisfaction of Amar Ma'ruf Nahi Munkar, the higher the profit sharing agreement. The result of this research supports the previous study result that the increase of the service toward the customers.

H5. The higher the profit sharing agreement for the building of profit sharing equity, the higher the halal repurchasing.

Hypothesis 3 is proven that the higher the profit sharing agreement for the building of profit sharing equity, the higher the halal repurchasing. The result of this research supports the previous study result that profit sharing system is very good from sharia point of view, because this system is fairer than interest system. Even interest system can be categorized as riba which is definitely haram. Generally, profit sharing system is a cooperation between two parties in doing business. The first party is the businessman who provides fund in expertise, skill, facility and time to manage the business. While the second party is the investors who own the fund to finance the business in order to be able to operate, either working capital, or entire.

\section{Conclusion of Research}

Based on the previous data analysis and discussion, this research produces conclusions as follows:

1) In accordance with data processing using AMOS 18, a conclusion can be drawn that the relationship between attributed satisfaction on Amar Ma'ruf Nahi Munkar (KBAN) and the quality of halal investment triangle (KSIH) has significant effect on halal repurchasing (PUH).

2) In accordance with data processing using AMOS 18, a conclusion can be drawn that the relationship between attributed satisfaction on amar ma'ruf nahi munkar (KBAN) and the profit sharing agreement $(\mathrm{KBH})$ has significant effect on halal repurchasing (PUH).

3) In accordance with data processing using AMOS 18, a conclusion can be drawn that the relationship between attributed satisfaction on amar ma'ruf nahi munkar (KBAN) has insignificant effect on halal repurchasing (PUH).

The guarantee that the capital will return is also not the characteristics of profit sharing business, because actually investors also have risks if their business keeps losing until they do not own their capital anymore [58]. Ref. [2], [50], stated that repurchase by the consumer is very important in maintaining profitability and business succeses. Ref. [2], [51] stated that loyal consumers are not measured from how much they purchase, but from how often they repuchase, including recommend other people to purchase.

TABL IV: DEVELOPMENT PATH ANALYSIS OF THE QUALITY OF HALAL INVESTMENT TRIANGLE

$\begin{array}{llll}\text { 1. } \mathrm{KBAN} \longrightarrow \mathrm{KSIH} \longrightarrow \text { PUH } & =(0,93)(0,63) & =0,58 \\ \text { 2. } \mathrm{KBAN} \longrightarrow \mathrm{KBH} \longrightarrow \text { PUH } & =(0,72)(0,20) & =0,14 \\ \text { 3. } \mathrm{KBAN} \longrightarrow \text { PUH (Effect of Direct }) & & =0,13\end{array}$

Source: result of data analysis, 2014. 
In this research, the purpose of path analysis to find which alternative path has the most significant effect on the final result of this research; halal repurchasing. Path alternative of satisfaction toward halal repurchasing can be seen through 3 (three) alternative path on the following Table III.

Based on the results of path analysis in Table $\mathrm{V}$, the path $\mathrm{KBAN} \longrightarrow \mathrm{KSIH} \longrightarrow \mathrm{PUH}$ is an alternative that has a greater value is 0,58 compared with lane $\mathrm{KBAN} \longrightarrow \mathrm{KBH}$ $\longrightarrow$ PUH sebesar 0,14 dan jalur KBAN $\longrightarrow$ PUH (Effect of Direct) by 0,13 .

According to the result of path analysis on Table $\mathrm{V}$, the path of $\mathrm{KBAN} \longrightarrow \mathrm{KSIH} \longrightarrow \mathrm{PUH}$ are alternatives which have bigger value of 0,58 compared to the paths of KBAN $\longrightarrow \mathrm{KBH} \longrightarrow \mathrm{PUH}$ of 0,14 and the paths of $\mathrm{KBAN} \longrightarrow$ PUH (direct effect) of 0,13 .

\section{CONCLUSION}

It can be concluded that the most efficient path analysis is the new concept of the quality of halal investment triangle in order to increase halal repurchasing of $\mathrm{KBAN} \longrightarrow$ $\mathrm{KSIH} \longrightarrow \mathrm{PUH}$ is 0,58 . It is also proven that the quality of halal investment triangle is as the highest mediation variable toward halal repurchasing compared with the steady variable, profit sharing variable $(\mathrm{KBH})$ of 0,14 . The effect is more meaningful if compared with the direct effect between KBAN and PUH (directly) of 0,13, while the effect of $\mathrm{KBAN}$ on PUH which mediation is $\mathrm{KSIH}$ is 0,58 .

\section{REFERENCES}

[1] J. K. Evans and N. Laskin, "Searching for a definition of relationship marketing," in Proc. the 3rd International Colloquium on Relationship Marketing, University of Melbourne, Melbourne, 1994.

[2] F. Reichheld and W. E. Sasser, Zero Defections: Quality Comes to Services, Harvard Business Review September-October, pp. 105-111, 1990.

[3] A. Karim, Miro Islamic Economics, King Grafindo Persada, 2008.

[4] Zeithaml et al., "Measuring the quality of relationships in customer service: An empirical study," Journal of Marketing, 1996.

[5] T. Eduardus, Investment Analysis and Portfolio Management, Yogyakarta: BPFE, 2001.

[6] Y. Kuncoro, Now the Time to Reach Shariah Mutual Funds Market, The Essays of Yoki, 2008.

[7] L. Guo, J. J. Xiao, and C. Tang, "Understanding the psychological process underlying customer satisfaction and retention in a relational service," Journal of Business Research, vol. 62, pp. 1152-1159, 2009.

[8] J. K. L. Keller, Marketing Management, Translation: Bob Sabran, The Publisher Grants, vol. 13.

[9] C. Munteanu, C. Ceobanu, C. Bobalca, and O. Anton, "An analysis of customer satisfaction in a higher education context," International Journal of Public Sector Management, vol. 23, no. 2, pp. 124-140, 2010.

[10] A. B. William, Creating Value for Customer: Designing and Implementation a Total Corporate Strategy, John Walley and Sons Inc, Canada, 1991.

[11] N. Kamal, A. Jamal, and K. A. Khatib, "Islamic banking: A study of customer satisfaction and preferences in jordan," International Journal of Bank Marketing, vol. 17, no. 3, 1999.

[12] M. H. K. Choudhury, Management Theory, Practice and Research Islamic Bank, PT Earth Literacy, Jakarta, 2005.

[13] C. Gan, D. Cohen, M. Cleme, and E. Chong, "A survey of customer retention in the new zealand banking industry," Banks and Bank Systems, vol. 1, no. 4, 2006.

[14] M. F. Hussain and S. Ilyas, "Environment for innovation: Gaining competitive advantage," African Journal of Business Management, vol. 5, no. 4, pp. 1232-1235, 2011.

[15] S. P. Juhaya, Philosophy of Islamic Law, London, UNISBA Press, 1995.
[16] A. Gozali, Deterioration of Law in Indonesia, Chalia Indonesia, Jakarta, 2003.

[17] K. Philip and A. Gary, Principles of Marketing, New Jersey: Prentice-Hall, Inc, 2012.

[18] S. B. Munir and R. Aditya, "Effect of emotional attachment experience and brand loyalty brand," Journal of Theoretical and Applied Management, vol. 4, no. 3, pp. 1-12.

[19] P. Zeithaml, "Multiple-ltem -a scale for measuring consumer perceptions of service quality," Journal of Retailing, vol. 64, no. 1, 2009.

[20] Suhari, "Triangle quality halal investing In murabahah sale and purchase agreement, purchase impact against re-halal," Shariah Marketing Journal of Economics, Diponegoro University, 2006.

[21] T. Eduardus, Investment Analysis and Portfo lio Management, Yogyakarta: BPFE, 2001.

[22] Y. Kuncoro, Now the Time to Reach Shariah Mutual Funds Market, 2000.

[23] E. Lestari, The Influence Factors on Performance of Corporate Governance Public Company Listed on the Jakarta Stock Exchange, Thesis Department of Accounting, Faculty of Economics, University of Indonesia, Jakarta, 2008.

[24] A. Hafidz, A. Aziz, and A. Rauf, Seventeen Motivation Interacts With the Koran, Mosque Habiburrahman, Bandung, 2008.

[25] F. Sepideh, G. Farhad, and H. Kambiz, "Investigating the effect of brand credibility on customer's loyalty in Iran's banking system," Journal of Management Research, vol. 88, pp. 69-88, 2011.

[26] S. H. Sofyan, Wiroso, and M. Yusuf, Accounting for Islamic Banking, Jakarta: LPFE Usakti, 1995.

[27] B. I. Syauqi, Islamic Banking and Real Sector Development, Jakarta, 2006.

[28] S. Fadjriah. (2007). Islamic System is More Suited for SME Financing. [Online]. Available: http://www.bisnis.com

[29] F. Harahap. Induction of Genetic Variation Mangosteen (Garcinia mangostana) with Gamma Ray Radiation, New York: Institute Bogor Agriculture, 2005.

[30] W. Dean et al., "Indications manajement, income tax act towards 2000 on manufacturing companies listed on the jakarta stock exchange," National Symposium on Accounting, Bali, vol. 11, 2004.

[31] A. Karim, Miro Islamic Economics, King Grafindo Persada, 2008.

[32] R. S. Ratna, "Effect of movement in the BI rate on the growth of third party funds (TPF) shariah bank," Thesis UPI, 2009.

[33] I. S. Beik, Islamic Banking and Real Sector Development, 2007.

[34] A. M. A. Fitr and E. Nasution, Comparison of Islamic banking industry profitability and banking conventional method using performance structure and behavior," Journal of Indonesian Economy and Development, vol. 3, January 2007.

[35] A. A. Karim, Islamic Economics, A Contemporary Study, Jakarta: Gema Insani Press, 2001.

[36] B. R. Supriyatni, "Discovery fatwa islamic law through the indonesian ulema council (MUI) in the field of islamic banking," Faculty of Law, Padjadjaran University: London, 2001.

[37] H. A. Shiddieqy, Lecture Worship; In Terms of Worship and Lesson Law, New York: Crescent Star, p. 1, 1987.

[38] O. Yan, Decision Theory, New York: University Publishing Center SBRC-Unisba, 1994.

[39] A. S. Dick and K. Basu, "Customer loyalty: Towards an integrated conceptual framework," Journal of the Academy of Marketing Science, vol. 22, no. 3, 1994.

[40] B. M. Van, K. D. Ruyter, and M. Wetzels, "The impact of incomplete information on the use of marketing research intelligence in international service settings," Journal of Service Research, vol. 2, no. 4, 2000.

[41] K. Philip and A. Gary, Principles of Marketing, grants, Jakarta, vol. 1, 2008.

[42] J. Jacoby and R. Chestnut, Brand Loyalty Measurement and Management, New York, NY: JohnWiley \&Sons, 1978.

[43] R. L. Oliver, "Whence customer loyalty?" Journal of Marketing, vol. 63, pp. 33-44, 1999.

[44] R. Faullant, K. Matzler, and J. Fuller, "The impact of satisfaction and image on loyalty: The case of alpine ski resorts," Managing Service Quality, vol. 18, no. 2, pp. 163-178, 2008.

[45] O. Giere, Meiobenthology, Springer, Berlin, p. 328, 1993.

[46] L. A. Simon and A. Manuela, "The influence of empowering leadership, empowerment and engagement on affective commitment and turnover intentions in community health services workers," Leadership in Health Services, vol. 24, no. 3, pp. 228-237, 2011.

[47] J. K. Harter, F. L.Schmidt, and C. L. Keyes, "Well-being in the workplace and its relation to bussiness outcome: A review of the gallup studies," American Psychological Association, 2002. 
[48] H. Thurau, K. P. Gwinner, and D. D. Gremler, "The rationales of service relationships : Integrating company-oriented and customeroriented relational benefits," American Marketing Association, vol. $11,2000$.

[49] M. Ali, "Strategy of islamic banking market development of nonmuslims," Paramadina University Journal, vol. 3, no. 1, 2003.

[50] R. Goodwin and B. Ball, Marketing What the CEO Wants to Know, pp. 18-23, 2003.

[51] E. Japarianto, Quality of Service Analysis as Measuring Customer Loyalty Hotel Majapahit Surabaya with Relational Marketing as an intervening Variable, pp. 34-42, 2007.

[52] H. Mothersbaugh, Customer Behaviour: Building Marketing Strategy, McGraw-Hill, New York, 2007.

[53] D. D. T. Sugiarto, Sitinjak Conquer Strategy Through Market Research Brand Equity and Behavior, New York: Scholastic Press, 2004.

[54] U. Sekaran, Research Methods for Business, John Willey and Sons, Inc. Canada.

[55] P. Kotler and K. L. Keller, Marketing Management, Translation: Bob, 2009.

[56] Kasmir, Bank and Other Financial Institutions, Jakarta: PT Raja Grafindo Persada, 2005.
[57] D. Diah "Impact analysis service performance and satisfaction," Journal of Marketing Management, vol. 1, no. 1.

[58] A. Gozali, Deterioration of Law in Indonesia, Chalia Indonesia, Jakarta, 2003.

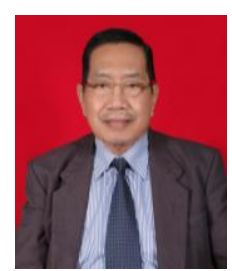

Suhari was born in 1943 in Pati, Central Java, Indonesia. He is a retired teacher from STM Negeri 1 Pati and a commissioner of PT. Jati Agung Group since 1977. He received his graduating undergraduate in program management from School of Economics BPD Central Java in 2006. He received his strata two in management program from Diponegoro University in 2008 . He received his three strata in field of economics doctoral program study marketing management from Faculty of Economics and Business, University of Diponegoro, in 2009. His area of research is in the field of marketing with quality titles Triangle Halal Investments in Murabaha Sale and Purchase Agreement, Impact on Repeat Purchase Halal (Research In BNI Syari'ah Customer Branch Semarang, Surakarta, Pekalongan, and Purwokerto in Central Java province of Indonesia). 